\title{
Cancer Chemoprevention by Garlic - A Review
}

\section{Pandrangi A*}

Department of Chemistry, Osmania University, Hyderabad, India

*Corresponding author: Anupama Pandrangi, Department of Chemistry, Osmania University, Hyderabad, India, Tel: 040 2768 2363; E-mail: p_anupama2002@yahoo.com

Rec Date: March 27, 2015, Acc Date: April 21, 2015, Pub Date: April 24, 2015

Copyright: $\odot 2015$ Pandrangi A. This is an open-access article distributed under the terms of the Creative Commons Attribution License, which permits unrestricted use, distribution, and reproduction in any medium, provided the original author and source are credited.

\begin{abstract}
Natural products remain an important source of new drugs, new drug leads and new chemical entities. They offer a great opportunity to evaluate totally new chemical classes of anticancer agents, as novel lead compounds with potentially relevant mechanisms of action. Numerous agents identified from fruits and vegetables can used in anticancer therapy, of which Allium vegetables, especially garlic, is one among them. The anticarcinogenic effect of garlic is attributed to organosulfur compounds (OSC) such as alliin, alliinase, allicin, S-allyl cysteine (SAC), diallyldisulphide (DADS), diallyltrisulphide (DATS) and methylallyltrisuphide, which are highly effective in affording protection against cancer. Other beneficial effects include anti-atherosclerosis, blood lipids and sugar modulation, antifungal, antimicrobial, antithrombotic, cardiovascular disease treatment and stimulating immune system. Chewing or cutting the bulbs of garlic activates the enzyme allinase which transforms the amino acid alliin to allicin which is a precursor to several sulphur containing compounds that are responsible for the flavour, odour and pharmacological properties of Allium sativum. An attempt has been made to review current knowledge on molecular targets of cancer chemoprevention by OSC present in garlic.
\end{abstract}

Keywords: Natural products; Allium vegetables; Garlic; OSC; Cancer chemoprevention

\section{Introduction}

For thousands of years, man has been using natural products of animals, plants and microbial sources either in the pure forms or crude extracts to treat many diseases [1]. Garlic (Allium sativum L.) is one of those plants that were seriously investigated over several years and used for centuries to fight infectious diseases [2]. Garlic is known in different names such as stinking rose, rustic treacle, poor man's treacle, Allium sativum, and camphor of the poor, maindenhair tree and nectar of the Gods.

For almost three thousand years Garlic (Allium sativum) has been used in medicines and foodstuff as evidenced by ancient writings from China, Egypt, Greece, and India [3,4]. Epidemiological studies have shown that the enhanced dietary intake of garlic could reduce the incidence of various types of tumors [5-11]. Other beneficial effects include anti-atherosclerosis [12], blood lipids and sugar modulation [13], antifungal [14], antimicrobial [15], antithrombotic [16], cardiovascular disease treatment [17] and stimulating immune system [18]. The most recent classification of garlic based on nuclear ribosomal DNA [19] is shown in Table 1 and pharmacological actions and health-promoting benefits of garlic are summarized in Table 2.

\begin{tabular}{|l|l|}
\hline Class & Liliopsida \\
\hline Subclass & Liliidae \\
\hline Superorder & Liliianae \\
\hline order & Amary-llidales \\
\hline Family & Alliaceae \\
\hline Subfamily & Allioideae \\
\hline Tribe & Allieae \\
\hline Genus & Allium \\
\hline
\end{tabular}

Table 1:Classification of garlic based on nuclear ribosomal DNA.

\begin{tabular}{|c|c|}
\hline Mechanisms of action & Health effect(s) \\
\hline Anticarcinogenic/Antimutagentic & $\begin{array}{l}\text { Inhibit cell division, induce apoptosis, block carcinogen activation, enhance } \\
\text { DNA repair, induce detoxifying enzymes }\end{array}$ \\
\hline Antimicrobial (antifungal, antiviral, antibacterial) & Inhibit microbiological growth as antibiotics \\
\hline Antioxidant & Scavenge oxidizing agents, induce SOD, GPX, GST, catalase \\
\hline Immunomodulatory & Increase proinflammatory cytokine release, stimulate natural killer cells \\
\hline Anti-hypolipidemic & Inhibit enzymes in cholesterol and fatty acid synthesis \\
\hline Anti-hypocholesterolemic & Inhibit cholesterol synthesis, enhance cholesterol turnover \\
\hline
\end{tabular}


Page 2 of 7

\begin{tabular}{|l|l|}
\hline Anti-hypertensive & Inhibit angiotensin II, induce NO and $\mathrm{H}_{2} \mathrm{~S}$, cause vasodilation \\
\hline Anti-diabetic & Stimulate insulin production, interfere glucose absorption \\
\hline Anti-thrombic & Reduce trombosane formation, change platelet membrane \\
\hline Hepatoprotective & Increase GSH levels by induction of GST \\
\hline
\end{tabular}

Table 2: Summary of garlic pharmacological actions and health-promoting benefits [20].

\section{Potentially active chemical constituents of garlic}

Allium sativum contains more than 100 biologically useful secondary metabolites, which include alliin, alliinase, allicin, S-allyl cysteine (SAC), diallyldisulphide (DADS), diallyltrisulphide (DATS) and methylallyltrisuphide. The $\gamma$-glutamyl-S-alk(en)yl-L-cysteines are the primary sulfur compounds in the intact garlic, which can be hydrolyzed and oxidized to yield S-alkyl(en) yl-L-cysteine sulfoxide (alliin). Chewing or cutting the bulbs of garlic activates the enzyme allinase which transforms the amino acid alliin to allicin which is a precursor to several sulphur containing compounds that are responsible for the flavour, odour and pharmacological properties of Allium. Allicin is highly unstable and instantly decompose to form various oil-soluble compounds involving diallyl sulfide (DAS), diallyl disulfide (DADS), diallyl trisulfide (DATS), vinyl dithiin and ajoene if conditions are appropriate [21]. At the same time, $\gamma$-glutamyl -Salk(en)yl-L-cysteines are also converted to water-soluble organosulfur compounds including S-allyl cysteine (SAC) and S-allyl mercaptocysteine (SAMC). Water-soluble organosulfur compounds are odorless and possess more delicate and less characteristic flavor compared to the oil-soluble organosulfur compounds [22]. Recent studies revealed that the antioxidant properties of garlic are due to presence of bioflavonoids quercetin and cyanidin [23]. The transformed pathways and chemical structures of the widely studied organosulfur compounds are depicted in Figure 1.

Apart from above said sulphur compounds, garlic also contains several enzymes; minerals germanium, calcium, copper, iron, potassium, magnesium, selenium, zinc; vitamins A, B1, C, amino acids, fiber and water [24].

\section{Mechanism of anticarcinogenic activity of garlic}

Possible anticarcinogenic mechanisms of garlic and its constituents may include the inhibition of carcinogen activation [25], the enhancement of detoxification [26], excretion [27], and the protection of DNA from activated carcinogens [28]. Furthermore, DATS reduced mitosis in tumors, decreased histone deacetylase activity, increased acetylation of $\mathrm{H} 3$ and $\mathrm{H} 4$, inhibited cell cycle progression, and decreased pro-tumor markers (survivin, Bcl-2, c-Myc, mTOR, EGFR, VEGF) [29]. Garlic components have been found to block covalent binding of carcinogens to DNA, enhance degradation of carcinogens, have anti-oxidative and free radical scavenging properties, and regulate cell proliferation, apoptosis, and immune responses. Ajoene, garlic-derived natural compound, have been shown to induce apoptosis in human leukemic cells via stimulation of peroxide production, activation of caspase-3-like and caspase-8 activity. Garlic synergizes the effect of a breast cancer suppressor, eicosapentaenoic acid, and antagonizes the effect of a breast cancer enhancer, linoleic acid [30].

\section{Modulation of activity of phase I and phase II metabolizing enzymes by garlic organosulfur compounds}

To protect all living organisms from environmental toxic effects biotransformation of xenobiotics is important. In mammalian systems these xenobiotic metabolizing enzymes are usually classified as phase I and phase II enzymes. Drug metabolism starts with phase I reactions, generally modifying the functional groups, while phase II reactions involve conjugation with endogenous compounds, thus facilitating the excretion from the body.

\section{Modulation of activity of phase I metabolizing enzymes}

Increased or decreased activities of specific CYP450 enzymes which play a key role in catalyzing the microsomal biotransformation of many xenobiotic compounds [31,32] can be directly beneficial by decreasing metabolism and/or increasing excretion of some carcinogens as well as by circumventing the DNA damage. Various garlic active components have been found to exert their chemopreventive effect by selectively enhancing or suppressing the levels of cytochrome $\mathrm{P} 450$ genes or proteins [32,33].

CYP2E1 is responsible for the activation of numerous carcinogenic chemicals [34]. The CYP2E1 enzyme kinetics studies performed using diallyl sulfide as a substrate have revealed that the sulfur atom on diallyl sulfide is oxidized by CYP2E1 to diallyl sulfone (DASO), then subsequently to diallyl sulfoxide (DASO2) and the final metabolite was an epoxide, generated by oxidation of the terminal double bond of $\mathrm{DASO}_{2}$, which bonded irreversibly to the CYP2E1 enzyme and lead to the autocatalytic destruction of the enzyme [35,36]. Diallyl sulfide (DAS), diallyl disulfide (DADS), and allyl mercaptan (AM) suppressed hepatic CYP2E1 protein expression and N-nitrosodimethylamine demethylase (NDMA) activity in a time- and NADPH-dependent manner [37] while the alkyl sulfides such as dipropyl sulfide (DPS), dipropyl disulfide (DPDS), and propyl methyl sulfide (PMS) did not inhibit the hepatic CYP2E1 protein expression, indicating that the alkenyl group on the organosulfur compounds may be critical for inhibiting the CYP2E1 enzyme [38].

\section{Modulation of activity of phase II metabolizing enzymes}

Garlic constituents may function as a double-edge sword in the prevention of chemically induced cancers by inhibiting carcinogen activation and enhancing detoxification of activated carcinogenic intermediates through the induction of Phase 2 enzymes [39-42] such as glutathione S-transferase (GST), epoxide hydrolase (EH), quinone reductase (QR), and UDPglucuronosyl transferase (UGT), [43]. Recently, special emphasis has been placed on the study of the effects of the garlic organosulfur compounds on the GST enzymes. GSTs are detoxification enzymes, that catalyze the conjugation of a wide variety of electrophiles and carcinogens with glutathione (GSH) [42]. Diallyl sulfide (DAS), allyl methyl disulfide (AMDS), allyl methyl trisulfide 
Page 3 of 7

(AMTS), diallyl disulfide (DADS), diallyl trisulfide (DATS), and S-allyl cysteine (SAC) compared to their corresponding saturated compounds in which propyl groups were substituted for the allyl groups were found to be an inducer of GST, catalyzing the conjugation of a wide variety of electrophiles and carcinogens with glutathione (GSH) in the forestomach, small-bowel mucosa, liver, colon and lung of mice [42,44-47]. DATS possessing triple sulfur bonds (-S-S-S) in its structure was found to be the most active than mono and di-sulfur compounds in the induction of detoxifying enzymes while the saturated analogs were almost without inhibitory activity, indicating the importance of the allyl group on the sulfides. Organosulfur compounds exert antitumor properties by up-regulation of the GST- $\alpha$, GST- $\mu$, and GST- $\pi[41,48-53]$. Lipid-soluble organosulfur compounds increased the activity of GST as well as other detoxifying enzymes such as epoxide hydrolase (EH), quinone reductase (QR), and UDPglucuronosyl transferase (UGT). Thus, it is reasonable to conclude that the induction of Phase 2 enzymes, especially GST, represents another potential mechanism to explain OSC-mediated prevention of chemically induced cancers.

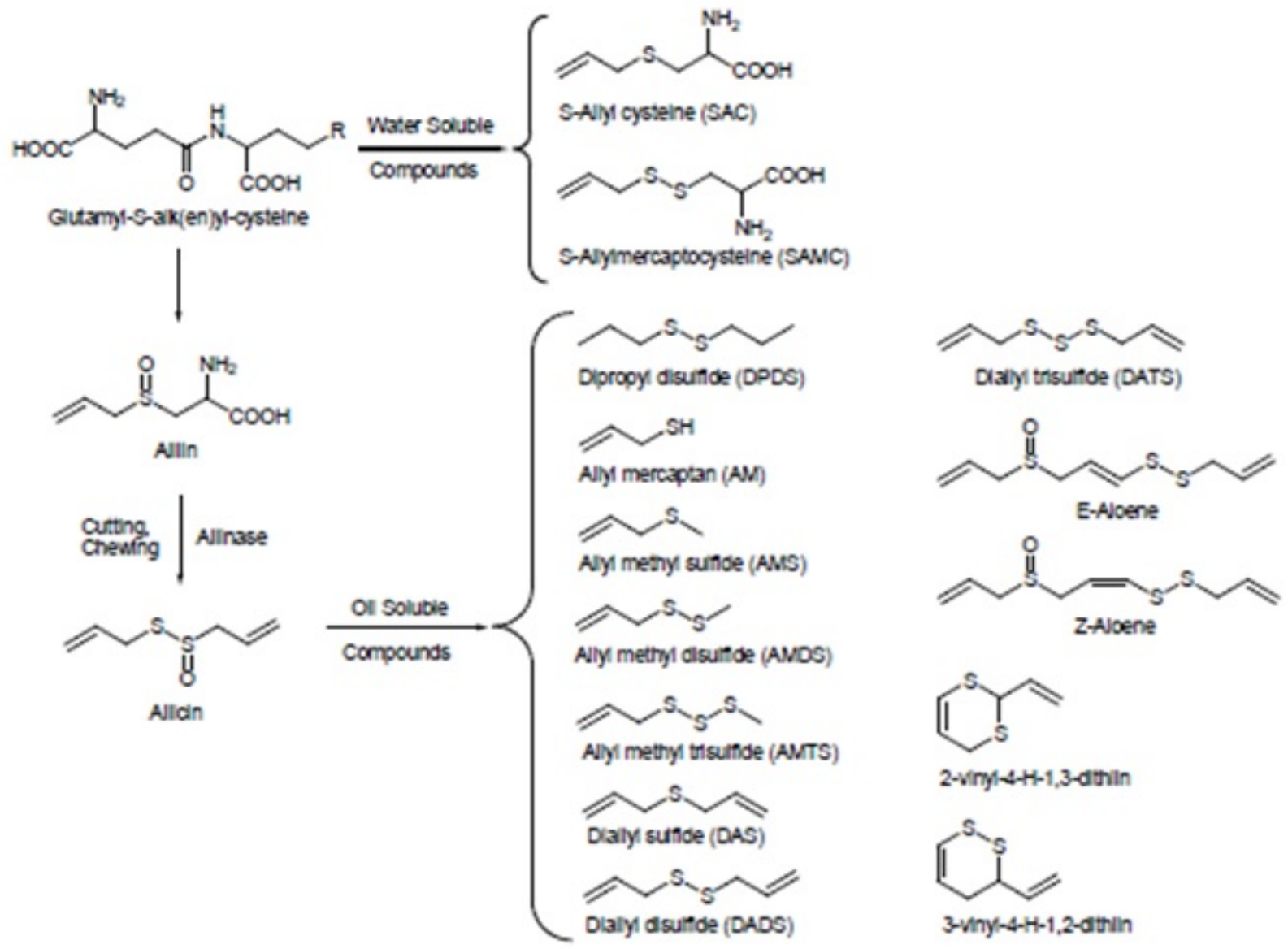

Figure 1: Chemical structures of commonly studied organosulfur compounds from garlic [20].

\section{Inhibition of post-translational modification of oncogenic} ras

Studies from Prof Shivendra V Singh laboratory have revealed that oral administration of DADS $(8.25,16.5$ and $33 \mu \mathrm{mol}, 3$ times per week beginning the day of tumor cell injection), but not its saturated analogue dipropyl disulfide, suppressed growth of $\mathrm{H}$-ras oncogene transformed tumor xenografts in nude mice without causing weight loss or any other side effects $[54,55]$.

\section{Inhibition of cell cycle progression}

Cellular stresses may activate signal transduction pathways, referred to as checkpoints, which ensure completion of phase specific events and protect against genomic instability or, in cases where the damage is too severe, switch the cell fate to programmed cell death $[56,57]$. Studies have shown that garlic-derived OSC can suppress growth of cancer cells of different anatomical locations in association with cell cycle arrest, mainly in the G2/M phase of the cell cycle. The DADSmediated G2/M phase cell cycle arrest in human colon cancer cells was accompanied by a decrease in the kinase activity of the Cdk1/cyclin B1 complex, reduction in complex formation between Cdk1 and cyclin $\mathrm{B} 1$, and a decrease in $\mathrm{Cdc} 25 \mathrm{C}$ protein level [58]. Thorough investigation of the mechanism of DATS-induced G2/M phase cell cycle arrest using PC-3 and DU145 human prostate cancer cells as a model [59-62] have revealed that DATS was much more effective than either DADS or DAS in causing G2/M phase cell cycle arrest [59] and further show that even a subtle change in OSC structure (the oligosulfide chain length) could have a significant impact on its 
Page 4 of 7

biological activity. Further studies on the DATS-treated PC-3 cells revealed that Chk1, which is an intermediary of DNA damage checkpoints [63], may regulate APC/C activity [61,63]. The mechanism of DATS-induced G2/M phase cell cycle arrest in human prostate cancer cells is shown in Figure 2.

Recent studies have revealed that DATS-mediated cell cycle arrest in human prostate cancer cells is linked to c-Jun N-terminal kinase (JNK)-dependent generation of reactive oxygen species (ROS) which appears to be caused by degradation of the iron-storage protein ferritin that leads to liberation of labile (chelatable) iron [62]. OSC affect the microtubule network in cancer cells that might initiate mitotic block or apoptosis. DATS has been shown to induce mitotic arrest in HCT-15 and DLD-1 human colon cancer cells in association with disruption of the microtubule network in interphase cells and inhibition of spindle formation in mitotic cells and further revealed DATS-mediated oxidative modification of tubulin $\beta$ at residues Cys12 and Cys354 [64]. Z-ajoene, an oil-soluble garlic compound caused G2/M phase cell cycle arrest and disruption of the microtubule network in normal marsupial kidney cells and inhibited tubulin polymerization in vitro [65]. A few reports have also shown that garlic-derived OSC arrest cancer cells in phases other than G2/M [66,67].

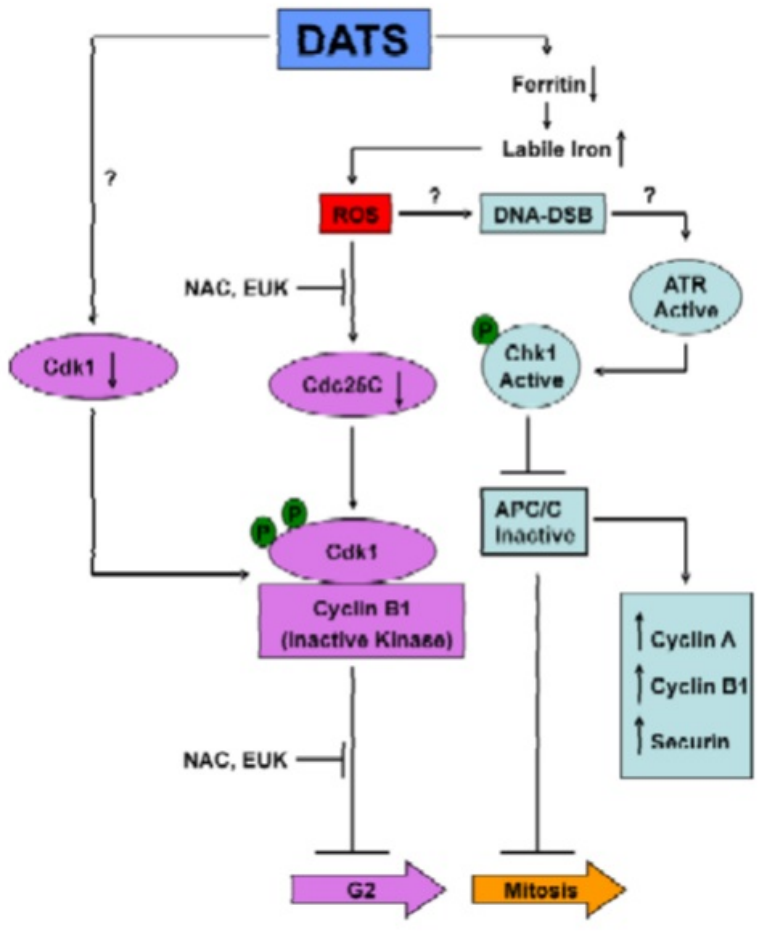

Figure 2: Proposed mechanisms to explain DATS-induced G2 and $\mathrm{M}$ phase cell cycle arrest in human prostate cancer cells [62].

\section{Histone modification}

OSC may affect cancer cell proliferation through modification of histone acetylation and, thus, regulation of gene expression [68].

\section{Induction of programmed cell death (apoptosis)}

Apoptosis (also known as programmed cell death) is a tightly controlled process whose dysregulation leads to numerous pathological conditions including cancer, therefore, apoptosis is a valid target in cancer therapy and prevention [69,70]. Garlic-derived OSC have been shown to modulate a number of key elements in cellular signal transduction pathways linked to the apoptotic process.

Intrinsic or mitochondria-mediated pathway in the execution of apoptosis, involves loss of mitochondrial membrane potential and release of apoptogenic molecules from the mitochondria to the cytosol [71,72] whose activation is regulated by the Bcl-2 family of antiapoptotic (Bcl-2 and Bcl-xL) and proapoptotic (eg Bax and Bak) proteins [73]. Garlic-derived OSC are believed to trigger apoptosis by modulating the levels of Bcl-2 proteins. The mechanism of DATSinduced apoptosis in human prostate cancer cells is summarized in Figure 3. ROS was found to play critical role as an intermediary of OSC-induced apoptosis $[74,75]$. OSC might also induce apoptosis from an increase in free intracellular calcium [76-80].

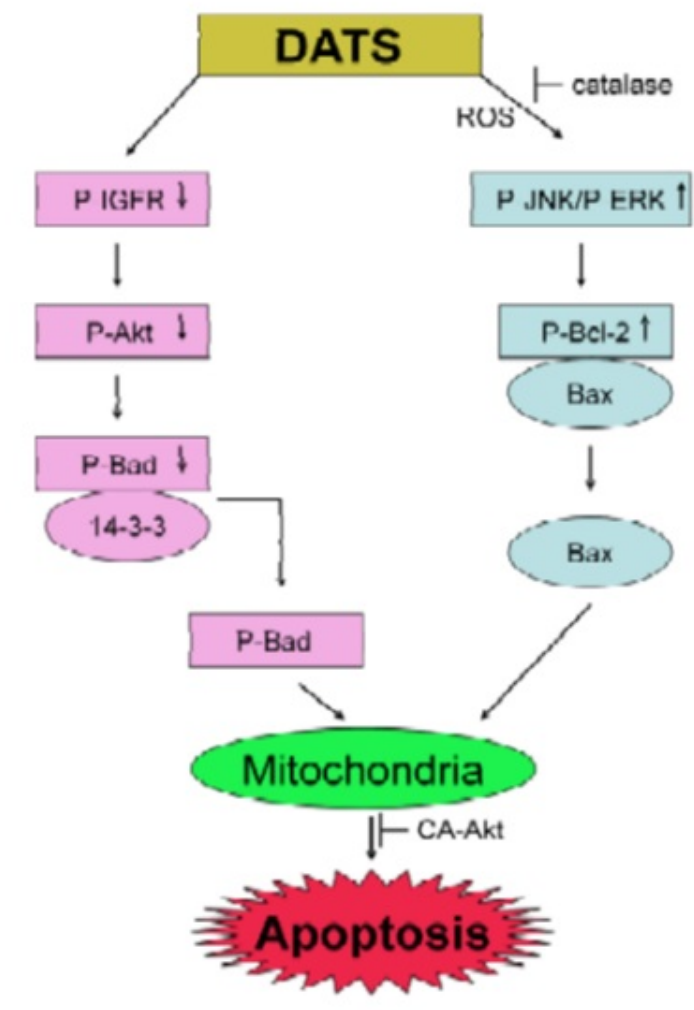

Figure 3: Proposed mechanisms for DATS-induced apoptosis in human prostate cancer cells [81].

\section{Inhibition of angiogenesis and metastasis by garlic constituents}

Studies by Matrigel chemoinvasion assay performed by Matsuura et al. [80] showed that aged garlic extract (AGE) suppressed proliferation of transformed human and rat endothelial cell lines and reduced the invasiveness of the endothelial cells by about $20 \%-30 \%$. Additional 
Page 5 of 7

tests that were conducted indicated that AGE increased the adhesion of the endothelial cells to collagen and fibronectin in a dose-dependent manner, thereby, reducing their motility and finally, AGE reduced capillary-like tube formation by the endothelial cells in a threedimensional collagen matrix assay [82]. Examination of the effects of DAS, DADS and DATS on human umbilical vein endothelial cell (HUVEC) viability have shown that DATS is the most potent of the three analogs in reducing the viability of HUVEC and was correlated with caspase 3 and PARP cleavage and apoptotic cell death [83]. The DATS treatment was able to significantly disrupt the capillary-like tube formation and migration by HUVEC which was accompanied by suppression of vascular endothelial growth factor (VEGF) secretion, downregulation of VEGF-Receptor 2 expression, inactivation of Akt and activation of ERK 1/2 [83]. Alliin was shown to reduce VEGF and fibroblast growth factor 2- (FGF-2) induced tube formation and angiogenesis in HUVEC and ex vivo in CAM assay [81]. Studies by Taylor et al. [84] have shown that ip injection of ajoene $(5-25 \mu \mathrm{g} / \mathrm{g}$ body weight) significantly inhibited pulmonary metastasis in C57BL/6 mice injected with B16/BL6 melanoma cells. Thus, based on the above reviewed studies it can be concluded that components of garlic extract (in combination or alone) present a great potential as antiangiogenic and antimetastatic agents [82-90].

\section{Modulation of multidrug resistance proteins and $\mathrm{P}$ - glycoproteins}

One of the major challenges of effective anticancer chemotherapy is multidrug resistance (MDR). There are two main transporter proteins involved in establishing the multidrug resistance in cancer cells: Pglycoprotein (P-gp) and multidrug resistance protein 2 (Mrp2) [91-93].

Development of MDR in human cancers such as leukemias, lymphomas, multiple myeloma, neuroblastoma, and soft tissue sarcoma has been related to the over-expression of the ATP-binding cassette transporter P-gp [93]. Mrp2 is an ATP-dependent transporter for organic anions that contributes to the drug resistance by transporting a wide range of glutathione, glucuronate and sulfate conjugates out of cells [94]. Organosulfur compounds present in garlic products have different effects on the P-glycoprotein (P-gp) and multidrug-resistant proteins (Mrp1 and Mrp2) in the chemotherapeutic treatments of various tumors and therefore further studies are required to clarify the mechanisms of organosulfur compounds in affecting the cancer multidrug resistance.

\section{Conclusion}

Research over the past 25 years has revealed that garlic derived OSC appear to target multiple pathways, including the cell cycle machinery, the intrinsic pathway for apoptotic cell death and angiogenic pathway, which may all contribute to their anticancer activities. Some garlic organo sulphur compounds have been shown to protect against toxicants and carcinogens by inhibition of enzymatic activation of protoxicants and by increasing tissue activities of enzymes that protect against electrophiles. The enhanced detoxification and liver protection of garlic organosulfur compounds could be attributed to the modulation of cytochrome P450 phase-I and II enzymes such as CYP2E1 and GST. Future research should focus on clinical assessment of these compounds for prevention/treatment of cancers in humans.

\section{Acknowledgment}

The author acknowledges Professor V. Uma, Head of the Department of Chemistry, Osmania University, for providing technical assistance in carrying out this work.

\section{References}

1. Suleria HAR, Butt MS, Khalid N, Sultan S, Raza A, et al. (2015) Garlic (Allium sativum): Diet based therapy of 21 st century-A Review. Asian Pacific Journal of Tropical Disease 5: 271-278.

2. Onyeagba R, Ugbogu OC, Okeke CU, Iroakasi O (2004) Studies on the antimicrobial effects of garlic (Allium sativum L.), ginger (Zingiber officinale Roscoe) and lime (Citrus aurantifolia L.). Afr J Biotechnol 3: 552-554.

3. Koch HP, Lawson LD (1996) Garlic: the science and therapeutic application of Allium sativum L. and related species (2ndedn), Williams and Wilkins, Baltimore, USA.

4. Suleria HAR, Butt MS, Anjum FM, Sultan S, Khalid N (2013) Aqueous Garlic Extract: Natural Remedy to Improve Haematological, Renal and Liver Status. J Nutr Food Sci 4: 252.

5. Fleischauer AT, Arab L (2001) Garlic and cancer: a critical review of the epidemiologic literature. J Nutr 131: 1032S-40S.

6. Lee SH (2009) Disulfide and multisulfide antitumor agents and their modes of action. Arch Pharm Res 32: 299-315.

7. Milner JA (2010) Garlic and Cancer Prevention. In: Milner JA, Romagnolo DF (eds.), Nutrition and Health: Bioactive Compounds and Cancer. New York, Dordrecht, Heidelberg, London.

8. Cerella C (2011) Naturally Occurring Organic Sulfur Compounds: An Example of a Multitasking Class of Phytochemicals in Anti-Cancer Research. In: Rasooli (1stedn). Phytochemicals - Bioactivities and Impact on Health. Croatia: InTech Europe.

9. Antosiewicz AH, Kawiak A, Antosiewicz J (2011) An Evidence-based Perspective of Allium Sativum (Garlic) for Cancer Patients. In: Cho WCS, (ed.) Evidence-based Anticancer Materia Medica, Evidence-based Anticancer Complementary and Alternative Medicine. New York, Dordrecht, Heidelberg, London.

10. Melino S, Sabelli R, Paci M (2011) Allyl sulfur compounds and cellular detoxification system: effects and perspectives in cancer therapy. Amino Acids 41: 103-112.

11. Rajendran P, Ho E, Williams DE, Dashwood RH (2011) Dietary phytochemicals, HDAC inhibition, and DNA damage/repair defects in cancer cells. Clin Epigenetics 3: 4.

12. Orekhov AN, Tertov VV, Sobenin IA, Pivovarova EM (1995) Direct antiatherosclerosis-related effects of garlic. Ann Med 27: 63-65.

13. Suleria HAR, Butt MS, Anjum FM, Ashraf M, Qayyum MMN, et al. (2013) Aqueous Garlic Extract Attenuates Hypercholesterolemic and Hyperglycemic Perspectives; Rabbit Experimental Modeling. Journal of Medicinal Plant Research vol 7: 1709-1717.

14. Davis SR (2005) An overview of the antifungal properties of allicin and its breakdown products--the possibility of a safe and effective antifungal prophylactic. Mycoses 48: 95-100.

15. Ruddock PS, Liao M, Foster BC, Lawson L, Arnason, JT, et al. (2005) Garlic Natural Health Products Exhibit Variable Constituent Levels and Antimicrobial Activity against Neisseria gonorrhoeae, Staphylococcus aureus and Enterococcus faecalis. Phytother Res 19: 327-334.

16. Ariga T, Seki T (2006) Antithrombotic and anticancer effects of garlicderived sulfur compounds: a review. Biofactors 26: 93-103.

17. Rahman K, Lowe GM (2006) Garlic and cardiovascular disease: a critical review. J Nutr 136: 736S-740S.

18. Sultan MT, Butt MS, Qayyum MM, Suleria HA (2014) Immunity: plants as effective mediators. Crit Rev Food Sci Nutr 54: 1298-1308.

19. Friesen N, Fritsch RM, Blattner FR (2006) Phylogeny and new intrageneric classification of Allium L (Alliaceae) based on nuclear ribosomal DNA its sequences. Aliso 22: 372-395. 
Page 6 of 7

20. Gao C, Jiang X, Wang H, Zhao Z, Wang W (2013) Drug Metabolism and Pharmacokinetics of Organosulfur Compounds from Garlic. J Drug Metab Toxicol 4: 1-10.

21. Brodnitz MH, Pascale JV, Derslice LV (1971) Flavor Components of Garlic Extract. J Agric Food Chem 19: 273-275.

22. Kodera Y, Suzuki A, Imada O, Kasuga S, Sumioka I, et al. (2002) Physical, chemical, and biological properties of s-allylcysteine, an amino acid derived from garlic. J Agric Food Chem 50: 622-632.

23. Alam S, Katiyar D, Goel R, Vats A, Mittal A (2013) Role of herbals in cancer management. The Journal of Phytopharmacology 2: 46-51.

24. Josling PA (2005) The heart of garlic Nature's aid to healing the human body. HEC Publishing, Chicago, Illinois.

25. Amagase H, Milner JA (1993) Impact of various sources of garlic and their constituents on, 12-dimethylbenz[a]anthracene binding to mammary cell DNA. Carcinogenesis 14: 1627-1631.

26. Sumiyoshi H, Wargovich MJ (1990) Chemoprevention of, 2dimethylhydrazine induced colon cancer in mice by naturally occurring organosulfur compounds. Cancer Res 50: 5084-5087.

27. Tadi PP, Lau BH, Teel RW, Herrmann CE (1991) Binding of aflatoxin B1 to DNA inhibited by ajoene and diallyl sulfide. Anticancer Res 11: 2037-2041.

28. Wallace GC, Haar CP, Vandergrift WA, Giglio P, Dixon-Mah YN, et al. (2013) Multi-targeted DATS prevents tumor progression and promotes apoptosis in ectopic glioblastoma xenografts in SCID mice via HDAC inhibition. J Neurooncol 114: 43-50.

29. Tsubura A, Lai YC, Kuwata M, Uehara N, Yoshizawa K (2011) Anticancer effects of garlic and garlic-derived compounds for breast cancer control. Anticancer Agents Med Chem 11:249-253.

30. Gonzalez FJ (1991) Human cytochrome P450: possible roles of drugmetabolizing enzymes and polymorphic drug oxidation in addiction. NIDA Res Monogr 111: 202-213.

31. Reicks MM, Crankshaw DL (1996) Modulation of rat hepatic cytochrome P-450 activity by garlic organosulfur compounds. Nutr Cancer 25: 241-248.

32. Yang CS, Wang ZY, Hong JY (1994) Inhibition of tumorigenesis by chemicals from garlic and tea. Adv Exp Med Biol 354: 113-122.

33. Brady JF, Li DC, Ishizaki H, Yang CS (1988) Effect of diallyl sulfide on rat liver microsomal nitrosamine metabolism and other monooxygenase activities. Cancer Res 48: 5937-5940.

34. Brady JF, Li DC, Ishizaki H, Yang CS (1988) Effect of diallyl sulfide on rat liver microsomal nitrosamine metabolism and other monooxygenase activities. Cancer Res 48: 5937-5940.

35. Brady JF, Ishizaki H, Fukuto JM, Lin MC, Fadel A, et al. (1991) Inhibition of cytochrome P-450 2E1 by diallyl sulfide and its metabolites. Chem Res Toxicol 4: 642-647.

36. Le Bon AM, Roy C, Dupont C, Suschetet M (1997) In vivo antigenotoxic effects of dietary allyl sulfides in the rat. Cancer Lett 114: 131-134.

37. Davenport DM, Wargovich MJ (2005) Modulation of cytochrome P450 enzymes by organosulfur compounds from garlic. Food Chem Toxicol 43: 1753-1762.

38. Sparnins VL, Barany G, Wattenberg LW (1988) Effects of organosulfur compounds from garlic and onions on benzo[a]pyrene-induced neoplasia and glutathione S- transferase activity in the mouse. Carcinogenesis 9: 131-134.

39. Hu X, Benson PJ, Srivastava SK, Mack LM, Xia H, et al. (1996) Glutathione S-transferases of female A/J mouse liver and forestomach and their differential induction by anti-carcinogenic organosulfides from garlic. Arch Biochem Biophys 336: 199-214.

40. Hu X, Singh SV (1997) Glutathione S-transferases of female A/J mouse lung and their induction by anticarcinogenic organosulfides from garlic. Arch Biochem Biophys 340: 279-286.

41. Hu X, Benson PJ, Srivastava SK, Xia H, Bleicher RJ, et al. (1997) Induction of glutathione S-transferase pi as a bioassay for the evaluation of potency of inhibitors of benzo(a)pyrene-induced cancer in a murine model. Int J Cancer 73: 897-902.
42. Andorfer JH, Tchaikovskaya T, Listowsky I (2004) Selective expression of glutathione S- transferase genes in the murine gastrointestinal tract in response to dietary organosulfur compounds. Carcinogenesis 25: 359-367.

43. Hayes JD, Pulford DJ (1995) The glutathione S-transferase supergene family: regulation of GST and the contribution of the isoenzymes to cancer chemoprotection and drug resistance. Crit Rev Biochem Mol Biol 30: 445-600.

44. Tadi PP, Teel RW, Lau BH (1991) Organosulfur compounds of garlic modulate mutagenesis, metabolism, and DNA binding of aflatoxin B1. Nutr Cancer 15: 87-95.

45. Sparnins VL, Mott AW, Barany G, Wattenberg LW (1986) Effects of allyl methyl trisulfide on glutathione S-transferase activity and BP-induced neoplasia in the mouse. Nutr Cancer 8: 211-215.

46. Sparnins VL, Barany G, Wattenberg LW (1988) Effects of organosulfur compounds from garlic and onions on benzo[a]pyrene-induced neoplasia and glutathione S-transferase activity in the mouse. Carcinogenesis 9: 131-134.

47. Sumiyoshi H, Wargovich MJ (1990) Chemoprevention of, 2dimethylhydrazine-induced colon cancer in mice by naturally occurring organosulfur compounds. Cancer Res 50: 5084-5087.

48. Reddy BS, Rao CV, Rivenson A, Kelloff G (1993) Chemoprevention of colon carcinogenesis by organosulfur compounds. Cancer Res 53: 3493-3498.

49. Hatono S, Jimenez A, Wargovich MJ (1996) Chemopreventive effect of Sallylcysteine and its relationship to the detoxification enzyme glutathione S-transferase. Carcinogenesis 17: 1041-1044.

50. Guyonnet D, Belloir C, Suschetet M, Siess MH, Le Bon AM (2001) Antimutagenic activity of organosulfur compounds from Allium is associated with phase II enzyme induction. Mutat Res 495: 135-145.

51. Chen HW, Tsai CW, Yang JJ, Liu CT, Kuo WW, et al. (2003) The combined effects of garlic oil and fish oil on the hepatic antioxidant and drug-metabolizing enzymes of rats. Br J Nutr 89: 189-200.

52. Tsai CW, Chen HW, Yang JJ, Sheen LY, Lii CK (2007) Diallyl disulfide and diallyl trisulfide up-regulate the expression of the pi class of glutathione S-transferase via an AP-1-dependent pathway. J Agric Food Chem 55: 1019-1026.

53. Zhang CL, Zeng T, Zhao XL, Xie KQ (2013) Garlic oil attenuated nitrosodiethylamine-induced hepatocarcinogenesis by modulating the metabolic activation and detoxification enzymes. Int J Biol Sci 234-237.

54. Singh SV, Mohan RR, Agarwal R, Benson PJ, Hu X, et al. (1996) Novel anti-carcinogenic activity of an organosulfide from garlic: Inhibition of H-RAS oncogene transformed tumor growth in vivo by diallyl disulfide is associated with inhibition of $\mathrm{p} 21 \mathrm{Hras}$ processing. Biochem Biophys Res Commun 22: 660 .

55. Singh SV (2001) Impact of garlic organosulfides on p21(H-ras) processing. J Nutr 131: 1046S-8S.

56. Molinari M (2000) Cell cycle checkpoints and their inactivation in human cancer. Cell Prolif 33: 261-274.

57. Murray AW (2004) Recycling the cell cycle: cyclins revisited. Cell 116: $221-234$

58. Knowles LM, Milner JA (2000) Diallyl disulfide inhibits p34 (cdc2) kinase activity through changes in complex formation and phosphorylation. Carcinogenesis. 1129-1133.

59. Xiao D (2005) Diallyl trisulfide-induced G (2)-M phase cell cyclcle arrest in human prostate cancer cells is caused by reactive oxygen speciesdependent destruction and hyperphosphorylation of Cdc25C. Oncogene 2: 6256-6266.

60. Herman-Antosiewicz A, Singh SV (2005) Checkpoint kinase 1 regulates diallyl trisulfide induced mitotic arrest in human prostate cancer cells. J Biol Chem 280: 28519-28522.

61. Herman-Antosiewicz A, Stan SD, Hahm ER, Xiao D, Singh SV (2007) Activation of a novel ataxia-telangiectasia mutated and Rad3 related/ checkpoint kinase 1-dependent prometaphase checkpoint in cancer cells 
by diallyl trisulfide, a promising cancer chemopreventive constituent of processed garlic. Mol Cancer Ther 1249.

62. Antosiewicz J, Herman-Antosiewicz A, Marynowski SW, Singh SV (2006) c-Jun $\mathrm{NH}(2)$-terminal kinase signaling axis regulates diallyl trisulfide-induced generation of reactive oxygen species and cell cycle arrest in human prostate cancer cells. Cancer Res 6: 5379.

63. Sanchez Y, Wong C, Thoma RS, Richman R, Wu Z, et al. (1997) Conservation of the Chk1 checkpoint pathway in mammals: linkage of DNA damage to Cdk regulation through Cdc25. Science 277: 1497-1501.

64. Hosono $\mathrm{T}$ (2005) Diallyl trisulfide suppresses the proliferation and induces apoptosis of human colon cancer cells through oxidative modification of beta-tubulin. J Biol Chem 280: 41487.

65. Li M, Ciu JR, Ye Y, Min JM, Zhang LH, et al. (2002) Antitumor activity of $Z$-ajoene, a natural compound purified from garlic: antimitotic and microtubule-interaction properties. Carcinogenesis 2: 573.

66. Zhang YW, Wen J, Xiao JB, Talbot SG, Li GC, et al. (2006) Induction of apoptosis and transient increase of phosphorylated MAPKs by diallyl disulfide treatment in human nasopharyngeal carcinoma CNE2 cells. Arch Pharm Res 2: 1125.

67. Lan H, Lu YY (2003) [Effect of allitridi on cyclin D1 and p27(Kip1) protein expression in gastric carcinoma BGC823 cells]. Ai Zheng 22: 1268-1271.

68. Lea MA, Randolph VM, Patel M (1999) Increased acetylation of histones induced by diallyl disulfide and structurally related molecules. Int J Oncol 15: 347-352.

69. Kaufmann SH, Gores GJ (2000) Apoptosis in cancer: cause and cure. Bioessays 22: 1007-1017.

70. Ghobrial IM, Witzig TE, Adjei AA (2005) Targeting apoptosis pathways in cancer therapy. CA Cancer J Clin 55: 178-194.

71. Hengartner MO (2000) The biochemistry of apoptosis. Nature 407: 770-776.

72. Thornberry NA, Lazebnik Y (1998) Caspases: enemies within. Science 281: 1312-1316.

73. Chao DT, Korsmeyer SJ (1998) BCL-2 family: regulators of cell death. Annu Rev Immunol 16: 395-419.

74. Kwon KB, Yoo SJ, Ryu DG, Yang JY, Rho HW, et al. (2002) Induction of apoptosis by diallyl disulfide through activation of caspase-3 in human leukemia HL-60 cells. Biochem Pharmacol 63: 41-47.

75. Filomeni G, Aquilano K, Rotilio G, Ciriolo MR (2003) Reactive oxygen species-dependent c-Jun $\mathrm{NH} 2$-terminal kinase/c-Jun signaling cascade mediates neuroblastoma cell death induced by dially disulphide. Cancer Res 5940 .

76. Karmakar S, Banik NL, Patel SJ, Ray SK (2007) Garlic compounds induced calpain and intrinsic caspase cascade for apoptosis in human malignant neuroblastoma SH-SY5Y cells. Apoptosis 1: 671.

77. Sundaram SG, Milner JA (1996) Diallyl disulfide inhibits the proliferation of human tumor cells in culture. Biochim Biophys Acta 1315: 15-20.
78. Sundaram SG, Milner JA (1996) Diallyl disulfide induces apoptosis of human colon tumor cells. Carcinogenesis 17: 669-673.

79. Park EK, Kwon KB, Park KI, Park BH, Jhee EC (2002) Role of Ca(2+) in diallyl disulfide-induced apoptotic cell death of HCT-15 cells. Exp Mol Med 34: 250-257.

80. Sakamoto K, Lawson LD, Milner JA (1997) Allyl sulfides from garlic suppress the in vitro proliferation of human A549 lung tumor cells. Nutr Cancer 29: 152-156.

81. Matsuura N, Miyamae Y, Yamane K, Nagao Y, Hamada Y, et al. (2006) Aged garlic extract inhibits angiogenesis and proliferation of colorectal carcinoma cells. J Nutr 136: 842S-846S.

82. Xiao D, Li M, Herman-Antosiewicz A, Antosiewicz J, Xiao H, et al. (2006) Diallyl trisulfide inhibits angiogenic features of human umbilical vein endothelial cells by causing Akt inactivation and down-regulation of VEGF and VEGF-R2. Nutr Cancer 55: 94-107.

83. Mousa AS, Mousa SA (2005) Anti-angiogenesis efficacy of the garlic ingredient alliin and antioxidants: role of nitric oxide and p53. See comment in PubMed Commons below Nutr Cancer 53: 104-110.

84. Taylor P, Noriega R, Farah C, Abad MJ, Arsenak M, et al. (2006) Ajoene inhibits both primary tumor growth and metastasis of B16/BL6 melanoma cells in C57BL/6 mice. Cancer Lett 239: 298-304.

85. Thejass $P$, Kuttan G (2007) Inhibition of angiogenic differentiation of human umbilical vein endothelial cells by diallyl disulfide (DADS). Life Sci 80: 515-521.

86. Thejass P, Kuttan G (2007) Antiangiogenic activity of Diallyl Sulfide (DAS). Int Immunopharmacol 7: 295-305.

87. Hu X, Cao BN, Hu G, He J, Yang DQ, et al. (2002) Attenuation of cell migration and induction of cell death by aged garlic extract in rat sarcoma cells. Int J Mol Med 9: 641-643.

88. Howard EW, Ling MT, Chua CW, Cheung HW, Wang X, et al. (2007) Garlic-derived S-allylmercaptocysteine is a novel in vivo antimetastatic agent for androgen-independent prostate cancer. Clin Cancer Res 13: 1847-1856.

89. Folkman J (2003) Fundamental concepts of the angiogenic process. Curr Mol Med 3: 643-651.

90. Borst P, Evers R, Kool M, Wijnholds J (2000) A family of drug transporters: the multidrug resistance-associated proteins. J Natl Cancer Inst 92: 1295-1302.

91. Gottesman MM, Fojo T, Bates SE (2002) Multidrug resistance in cancer: role of ATP-dependent transporters. Nat Rev Cancer 2: 48-58.

92. Gillet JP, Gottesman MM (2010) Mechanisms of multidrug resistance in cancer. Methods Mol Biol 596: 47-76.

93. Lee $\mathrm{CH}$ (2010) Reversing agents for ATP-binding cassette drug transporters. Methods Mol Biol 596: 325-340.

94. Kast HR, Goodwin B, Tarr PT, Jones SA, Anisfeld AM, et al. (2002) Regulation of multidrug resistance-associated protein 2 (ABCC2) by the nuclear receptors pregnane $\mathrm{X}$ receptor, farnesoid $\mathrm{X}$-activated receptor and constitutive androstane receptor. J Biol Chem 27: 2908-3291. 